\title{
IDENTIFIKASI STRATEGI INTERVENSI SISTEM USAHA PERIKANAN UNTUK MENINGKATKAN PASOKAN IKAN DI LOKASI RAWAN PANGAN
}

\author{
Yayan Hikmayani, Rani Hafsaridewi dan Agus Heri Purnomo' \\ ${ }^{1}$ Peneliti Pada Balai Besar Riset Sosial Ekonomi Kelautan dan Perikanan \\ JI. KS Tubun Petamburan VI Jakarta 10260. \\ Telp. (021)53650162, Fax. (021)53650159 \\ Diterima 23 Maret 2010 - Disetujui 4 april 2010
}

\begin{abstract}
ABSTRAK
Penelitian terkait dengan pengembangan sistem usaha perikanan dalam rangka mendukung ketahanan pangan telah dilakukan pada Tahun 2009, di lokasi-lokasi yang mewakili wilayah-wilayah yang oleh Badan Ketahanan Pangan dikategorikan sebagai rawan pangan. Metode penelitian yang dilakukan adalah studi kasus, dengan data yang dikumpulkan menggunakan metode survey. Responden terdiri dari pelaku usaha budidaya ikan dan masyarakat yang dipilih secara purposif masing-masing dari satu desa di kabupaten-kabupaten yang dinyatakan paling rawan pangan terpilih. Pengolahan data dilakukan secara deskriptif dan modeling, untuk mengetahui strategi dalam pengembangan usaha budidaya guna pemenuhan konsumsi ikan ideal oleh masyarakat. Hasil penelitian menunjukkan perlu adanya pembedaan strategi pengembangan sistem usaha perikanan di setiap lokasi, tergantung potensi lokasi masing-masing. Strategi pertama dilakukan dengan mengembangkan usaha perikanan mencakup sistem usaha budidaya mulai dari pembenihan sampai pembesaran serta penumbuhan usaha penyedia jasa input. Strategi lainnya yaitu dengan meningkatkan usaha perikanan yang ada di darah lain terdekat guna mensuplai kebutuhan ikan untuk konsumsi ikan di lokasi rawan pangan. Strategi intervensi dimaksud dapat dilakukan upaya intensifikasi dan ekstensifikasi usaha budidaya.
\end{abstract}

Kata Kunci: strategi intervensi, sistem usaha perikanan, ketahanan pangan, rawan pangan

\section{Abstract : Development Strategy of Fisheries Farming System to Support Food Security at Food Shortage Areas}

This research was to assess fisheries farming system development in supporting food security program in selected food shortage areas according to definition of the Food Security Agency, the Ministry of Agriculture. Research was conducted in 2009 and used survey method. Respondent was selected by using purposive sampling method. Primary and secondary data were used in this study. Data processing was carried out descriptively by using the System Dynamics Modeling Approach to find out appropriate strategy for developing fisheries farming system. Results showed that the fisheries farming system development at each location has different strategy depending on its potential resource. The first proposed strategy is to provide fisheries farming system, starting from seed production to nursery and grow-out culture activities, as well as to develop provider of business inputs. Another strategy is to improve existing fisheries farming system in the areas nearby to supply the needs of fish consumption in food shortage locations.

Keywords: intervention strategy, fishers, enterprise system 


\section{PENDAHULUAN}

Sebagai salah satu sumber protein, ikan berpotensi memainkan peran penting dalam program ketahanan pangan terutama ketahanan gizi masyarakat. Widya Karya Nasional Pangan dan Gizi VI telah merekomendasikan standar kecukupan nasional pangan dan gizi untuk kecukupan protein sebesar $50 \mathrm{gram}$ protein/kapita/hari dan energi sebesar 2,200 Kkal/kapita/hari. Dari angka kecukupan protein rata-rata per kapita per hari tersebut dianjurkan sebanyak 18 gram diantaranya dipenuhi dari pangan sumber protein hewani, dengan perincian 6 gram berasal dari ternak dan 12 gram berasal dari ikan.

Ikan dihasilkan selain dari penangkapan, juga dihasilkan dari budidaya. Kondisi sumber daya ikan dari penangkapan saat ini tidak dapat diharapkan akan dapat menyuplai kebutuhan untuk konsumsi karena kondisi sumber daya yang sebagian wilayahnya mengalami overfishing. Salah satu sektor andalan yang masih dapat diupayakan yaitu mengembangkan usaha budidaya ikan sehingga dapat meningkatkan produksinya sehingga dapat menggantikan kekurangan sumber ikan yang tidak dapat disediakan oleh usaha penangkapan. Peningkatan produksi ikan hasil budidaya harus dilakukan melalui pendekatan sistem usaha budidaya yang baik, sehingga pemenuhan protein untuk menjaga ketahanan pangan rumah tangga dapat dipenuhi.

Pengembangan usaha perikanan di lokasi rawan pangan pun sangat memungkinkan dilakukan. Faktor yang penting adalah adanya sumber daya yang cukup untuk mendukung usaha tersebut dapat dilakukan seperti ketersediaan air, infrastruktur, serta sumber daya manusia sebagai pelaksana kegiatan usaha. Melalui tulisan ini ingin dilihat bagaimana strategi intervensi terhadap sistem usaha perikanan yang harus dilakukan untuk meningkatkan pasokan ikan bagi konsumsi rumah tangga di lokasi rawan pangan.

\section{METODOLOGI}

\section{Lokasi dan Waktu Penelitian}

Penelitian terkait dengan sistem usaha perikanan yang mendukung ketahanan pangan telah dilakukan pada tahun 2009 . Lokasi penelitian dipilih secara sengaja (purposive) yaitu desa yang tercatat sebagai lokasi rawan pangan selama tiga tahun berturut-turut dari data Statistik Kerawanan Pangan dan Gizi yang dikeluarkan oleh Badan Ketahanan Pangan, Departemen Pertanian. Banyaknya lokasi desa dipilih 3 desa di tiga kabupaten dan tiga propinsi yang ada di Jawa Tengah, Jawa Timur dan Jawa Barat. Setelah dilakukan identifikasi maka terpilih 3 desa yaitu di Jawa Tengah (Desa Watuurip, Kec. Padang, Kabupaten Banjarnegara), DIY (Desa Salamredjo, Kecamatan Sentolo Kab.Kulonprogo) dan Jawa Timur (Desa Merakan, Kecamatan Padang, Kabupaten Lumajang).

\section{Data dan Sumber Data}

Penelitian dilakukan dengan menggunakan metode survey. Jenis data yang dikumpulkan terdiri dari data primer dan sekunder. Responden dipilih secara purposif sebanyak 30 orang terdiri dari pelaku usaha budidaya ikan dan masyarakat yang berada di lokasi desa rawan pangan. Data primer diperoleh melalui wawancara langsung dengan responden menggunakan kuesioner terstruktur. Topik-topik pertanyaan yang tercakup dalam kuesioner adalah karakteristik responden, faktor-faktor dalam sistem usaha perikanan, data tentang ketahanan pangan terkait dengan konsumsi ikan responden yang meliputi stabilitas, keterjangkauan, ketersediaan dan keamanan pangan. Data sekunder diperoleh melalui studi literatur maupun laporan yang dikeluarkan oleh institusi terkait baik pusat maupun daerah yang terkait dengan ketahanan pangan serta pengembangan usaha perikanan.

\section{Analisis Data}

Pengolahan data dilakukan secara deskriptif tabulatif dan modeling. Modeling 
berguna untuk merekonstruksi hubungan antara skenario intervensi strategi tertentu dalam pengembangan usaha budidaya dengan output dari skenario intervensi yang terpilih dalam kaitannya untuk pemenuhan konsumsi ikan ideal oleh masyarakat di desa tersebut. Pemodelan menggunakan piranti lunak powersim, yang dikembangkan atas dasar model sistem dinamik, digunakan untuk membantu rekonstruksi tersebut. Tabulasi data dan rekonstruksi skenario diuji validitasnya melalui diskusi kelompok fokus, untuk melihat kesesuaiannya dengan kondisi riil di lapangan. Acuan utama dari diskusidiskusi kelompok fokus digunakan kerangka agribisnis yang dikemukakan oleh Saragih (2001), dimana sistem usaha perikanan diusahakan dengan memperhatikan keterkaitan antara subsistem. Subsistem yang dimaksud meliputi subsistem produksi (usaha budidaya), subsistem input produksi, subsistem pengolahan, subsistem pemasaran. Tahapan pemodelan dengan powersim dapat dilihat di Gambar 1.

Proses membangun model dinamik dengan powersim tersebut digunakan enam (6) langkah pemodelan, yaitu:

1. Pemetaan sistem nyata. Langkah pertama dalam pemodelan ini adalah membuat diagram simpal kausal atau causal loop diagram (CLD).

2. Pembuatan model. Langkah kedua adalah membangun diagram alir atau stock flow diagram (SFD).

3. Input data. Langkah ketiga yang dilakukan dalam proses pemodelan adalah memasukkan data pada variabelvariabel yang sudah dibentuk dalam SFD.

4. Simulasi. Langkah keempat adalah membuat simulasi model SFD yang sudah dibangun.

5. Validasi. Langkah kelima adalah memvalidasi model, karena validitas atau
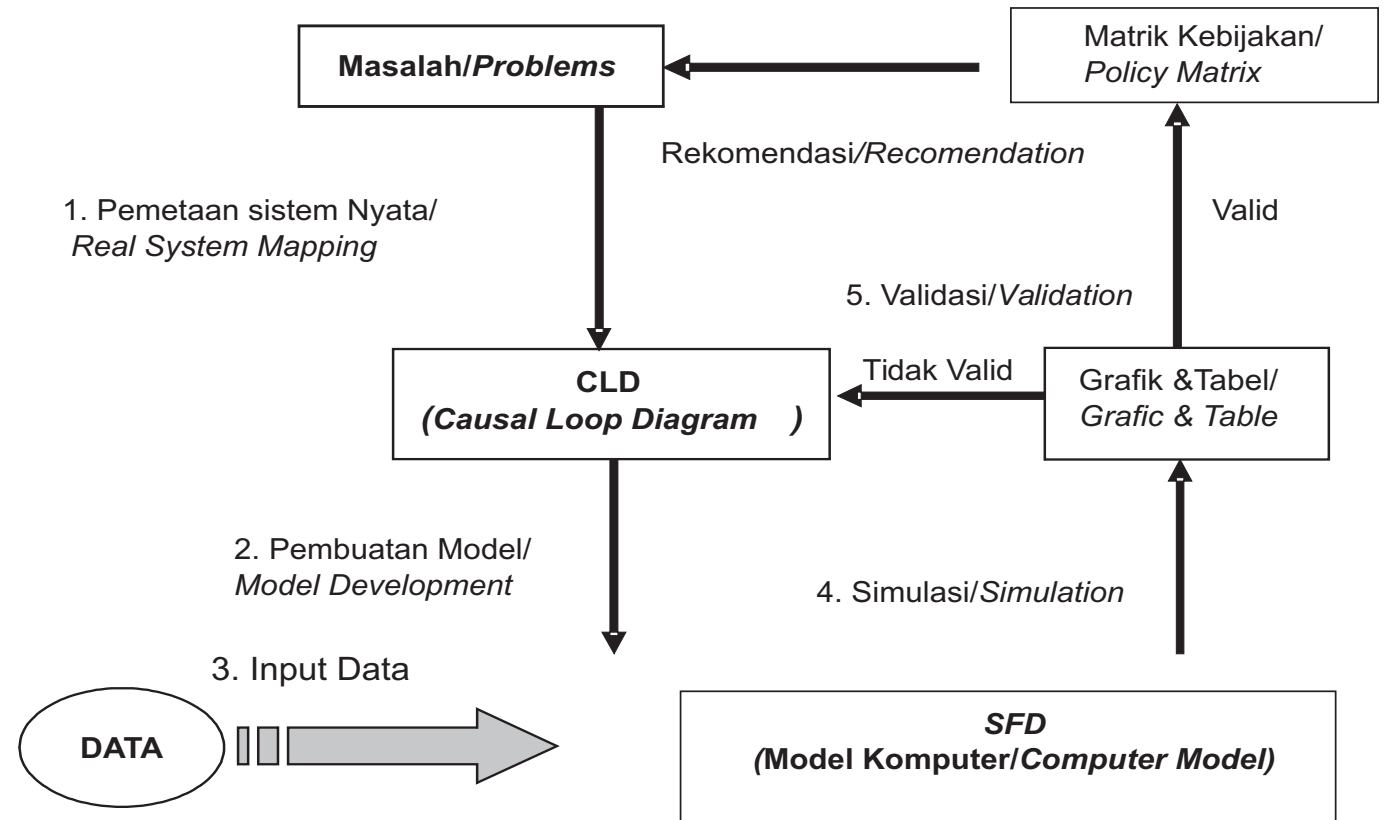

$S F D$

(Model Komputer/Computer Model) 
keabsahan adalah salah satu kriteria penilaian keobyektifan dari suatu pekerjaan ilmiah. Validasi model adalah penilaian keabsahan suatu model.

\section{Validasi Data}

Validasi atau keabsahan adalah salah satu kriteria penilaian keobyektivan dari suatu pekerjaan ilmiah. Di dalam membangun sebuah model, objektif ditunjukkan dengan sejauhmana model dapat menirukan fakta (Muhammadi, 2001:343). Ada dua kategori validasi model, yaitu:

1. Validitas Struktur adalah melihat sejauh mana struktur model menyerupai struktur sistem nyata. Teknik yang dilakukan melalui: empirical test, theoretical test, implementation method (seperti formal review), dan structure-orientated behavior test (seperti boundary adequacy test).

2. Validitas Perilaku adalah melihat sejauh mana perilaku hasil model dapat menirukan perilaku sistem nyata. Teknik yang dilakukan adalah dengan menggunakan statistik. Uji statistik yang dilakukan adalah dengan melihat Absolute Mean Error (AME). Rumus yang digunakan ialah:

$$
\begin{aligned}
\mathrm{AME} & =\left|\left(\underline{\mathrm{S}}_{\mathrm{i}}-\underline{\mathrm{A}}_{\mathrm{i}}\right)\right| / \underline{\mathrm{A}}_{\mathrm{i}} \\
\underline{\mathrm{S}}_{\mathrm{i}} & =\Sigma \mathrm{S}_{\mathrm{i}} / \mathrm{N} \\
\underline{\mathrm{A}}_{\mathrm{i}} & =\Sigma \mathrm{A}_{\mathrm{i}} / \mathrm{N}
\end{aligned}
$$

Model dapat dinyatakan valid jika penyimpangan antara hasil simulasi dan data aktual < 10\% (Muhammadi, 2000).

\section{HASIL DAN PEMBAHASAN}

\section{Karakteristik Responden di Lokasi Survey}

Karakteristik responden dalam tulisan ini meliputi tingkat pendidikan, umur, matapencaharian, pendapatan serta pengeluaran rumah tangga seperti tertera pada Tabel 1.
Dari karakteristik pendidikan, sebagian besar responden di Desa Merakan dan Desa Watuurip tamat pendidikan dasar (SD), sedangkan di Desa Salamredjo sebagian besar responden berpendidikan sampai tamat Sekolah Lanjutan Atas ( SLTA). Dengan demikian, sumber daya dapat dikatakan bahwa responden di Desa Salamredjo mempunyai akan memiliki tingkat pengetahuan lebih tinggi di banding di dua desa lainnya.

Dari karakteristik umur responden, responden di ketiga lokasi didominasi pada kisaran usia 25 sampai 44 tahun. Hal ini menunjukkan bahwa kisaran umur responden tergolong kepada usia produktif. Dari sisi usia tersebut sumber daya manusia di ketiga lokasi merupakan potensi yang dapat dikembangkan untuk mendorong upaya pengembangan usaha perikanan.

Dari sisi matapencaharian, sebagaian besar responden di ketiga lokasi merupakan buruh tani yang bekerja di lahan pertanian maupun perkebunan yang ada di desa tersebut. Pekerjaan budidaya ikan merupakan pekerjaan sambilan disamping pekerjaan utamanya. Namun demikian, dengan meningkatnya peran usaha perikanan sebagai penyumbang keuangan keluarga seperti yang terjadi di Desa Salamredjo dan Desa Watuurip. Di kedua desa tersebut kegiatan budidaya ikan cukup intensif dilakukan.

Dari data pendapatan responden, sebagian besar reponden berpenghasilan kurang dari Rp. 500.000 kecuali di Desa Merakan. Dari pendapatan sebesar itu paling besar dikeluarkan untuk pembelian ikan, yaitu Rp. 100.000 per bulan. Dibandingkan dengan sumber protein hewani lain. Hal ini menunjukkan bahwa konsumsi ikan responden di lokasi tersebut lebih tinggi dibanding konsumsi selain ikan. Konsumsi terhadap daging pada umumnya hanya terjadi pada hari besar keagamaan dan perayaan keluarga. Dari informasi tersebut dapat dikatakan bahwa peran ikan dalam konsumsi 
Tabel 1. Karakteristik Responden yang Dominan di Lokasi Survei

Table 1. Dominant Characteristics of Respondents on Survey Location

\begin{tabular}{llll}
\hline \multicolumn{1}{c}{$\begin{array}{c}\text { Uraian/ } \\
\text { Description }\end{array}$} & $\begin{array}{c}\text { Desa Salamredjo, } \\
\text { Kec. Sentolo, Kab. } \\
\text { Kulonprogo }\end{array}$ & $\begin{array}{c}\text { Desa Merakan, Kec. } \\
\text { Padang, Kab. } \\
\text { Lumajang }\end{array}$ & $\begin{array}{c}\text { Desa Watuurip, } \\
\text { Kec. Padang, Kab. } \\
\text { Banjarnegara }\end{array}$ \\
\hline $\begin{array}{c}\text { Tingkat Pendidikan/ } \\
\text { Education }\end{array}$ & $\begin{array}{l}\text { Tamat SLTA/High } \\
\text { School Graduated }\end{array}$ & $\begin{array}{c}\text { Tamat } \\
\text { SD/Elementary } \\
\text { School Graduated }\end{array}$ & $\begin{array}{c}\text { Tamat } \\
\text { SD/Elementary } \\
\text { School Graduated }\end{array}$ \\
\hline $\begin{array}{l}\text { Umur (tahun)/Age (Year) } \\
\text { Pekerjaan/Occupation }\end{array}$ & $\begin{array}{l}\text { Suruh tani/ } \\
\text { Buruh }\end{array}$ & $\begin{array}{l}\text { Buruh tani/ } \\
\text { Farmworker }\end{array}$ & $\begin{array}{l}\text { Farmworker } \\
\text { Tani/Farmer }\end{array}$ \\
$\begin{array}{l}\text { Pendapatan (Rp/bulan)/ } \\
\text { Income (Rp/month) }\end{array}$ & $<500.000$ & $500.000-$ & $<500.000$ \\
$\begin{array}{l}\text { Pengeluaran RT untuk ikan } \\
\text { (Rp/bulan)/ Household }\end{array}$ & $50.000-<100.000$ & $50.000-<100.000$ & $50.000-100.000$ \\
$\begin{array}{l}\text { Expenditure for fish } \\
\text { consumption (Rp/month) }\end{array}$ & & & \\
\hline
\end{tabular}

Sumber/ Source: Data primer, diolah (2009)/ Primary data, processed (2009)

rumah tangga di desa rawan pangan dianggap penting, karena makan ikan sudah menjadi kewajiban walaupun tidak mampu menyediakannnya setiap hari karena termasuk mahal.

\section{Sistem Usaha Perikanan di Desa Rawan Pangan}

Sistem usaha perikanan meliputi usaha mulai dari sektor hulu (on farm) yang meliputi usaha pembenihan, pendederan dan usaha pembesaran. Disamping itu didukung oleh sub sistem yang paling penting yaitu usaha sektor Hilir (off farm) sebagai usaha pendukung keberhasilan usaha perikanan yaitu usaha penyedia input produksi, jasa permodalan dan jasa pemasaran.

Dari hasil survey yang dilakukan di ketiga desa rawan pangan, dua desa yaitu Salamredjo dan Watuurip usaha perikanannya sudah berkembang. Usaha perikanan yang dilakukan di Desa Watuurip yaitu pembenihan dan pendederan. Benih yang dihasilkan di desa tersebut dijual ke luar daerah ke lokasilokasi pembesaran. Responden yang melakukan usaha pembesaran jumlahnya masih sedikit. Responden di Desa Salamredjo melakukan kegiatan usaha perikanan yaitu pembesaran ikan lele menggunakan terpal. Walaupun kondisi air di Desa Salamredjo cukup sulit, namun melalui teknologi budidaya yang dikembangkan telah berhasil menjadikan usaha budidaya lele tersebut sebagai usaha yang cukup menguntungkan. Berbeda dengan kondisi dua desa lainnya, di Desa Merakan usaha budidaya masih belum banyak dilakukan. Sampai saat survey dilakukan, baru dua orang yang baru melakukan usaha budidaya lele dan nila. Namun demikian, pengembangan budidaya sangat mungkin dilakukan dengan teknologi penyaluran air dari sumber ke lokasi penduduk. Lokasi-lokasi sumber air tersebut cukup banyak di Desa Merakan.

Usaha sektor hilir (off farm) yang mendukung pengembangan usaha budidaya ikan masih kurang optimal mendukung sistem usaha perikanan yang lebih baik. Hal ini disebabkan masih minimnya ketersediaan benih, pakan, jasa permodalan dan pasar. Untuk lebih jelasnya kondisi sistem usaha perikanan serta sub sistem pendukungnya yang ada dilokasi dapat dilihat pada Tabel 2 . 
Tabel 2. Kondisi Sistem Usaha Perikanan di Lokasi Survei

Table 2. The Condition of Fisheries Farming in Survey Location

\begin{tabular}{|c|c|c|c|}
\hline $\begin{array}{c}\text { Uraian/ } \\
\text { Description }\end{array}$ & $\begin{array}{l}\text { Desa Salamredjo, } \\
\text { Kec. Sentolo, Kab. } \\
\text { Kulonprogo }\end{array}$ & $\begin{array}{c}\text { Desa Merakan, Kec. } \\
\text { Padang, Kab. } \\
\text { Lumajang }\end{array}$ & $\begin{array}{c}\text { Desa Watuurip, Kec. } \\
\text { Padang, Kab. } \\
\text { Banjarnegara }\end{array}$ \\
\hline \multicolumn{4}{|l|}{ Off farm } \\
\hline $\begin{array}{l}\text { - Penyedia pakan/ } \\
\text { feed providers }\end{array}$ & $\begin{array}{l}\text { Sudah tersedia di } \\
\text { lokasi/ available on } \\
\text { location }\end{array}$ & $\begin{array}{l}\text { Belum tersedia, ada } \\
\text { di kota } \\
\text { kecamatan/not } \\
\text { available on location } \\
\text { but available on sub } \\
\text { district center }\end{array}$ & $\begin{array}{l}\text { Sudah tersedia/ } \\
\text { available on location }\end{array}$ \\
\hline $\begin{array}{l}\text {-Penyedia benih ikan/ } \\
\text { Juvenile providers }\end{array}$ & $\begin{array}{l}\text { Sudah ada, masih } \\
\text { sedikit/ available on } \\
\text { location but still slightly }\end{array}$ & $\begin{array}{l}\text { Belum ada, ada di } \\
\text { desa tetangga/ not } \\
\text { available, but } \\
\text { available on } \\
\text { neighboring village }\end{array}$ & $\begin{array}{l}\text { Sudah banyak/ very } \\
\text { available }\end{array}$ \\
\hline Pasar/ Market & $\begin{array}{l}\text { Ada, di desa/ available } \\
\text { on village }\end{array}$ & $\begin{array}{l}\text { Ada di desa/ } \\
\text { available on village }\end{array}$ & $\begin{array}{l}\text { Ada di desa/ } \\
\text { available on village }\end{array}$ \\
\hline \multicolumn{4}{|l|}{ On farm } \\
\hline Usaha pembenihan/ & $\begin{array}{l}\text { Sudah ada, masih baru } \\
\text { satu orang/ available } \\
\text { but just one person }\end{array}$ & $\begin{array}{l}\text { Belum ada/ not } \\
\text { available }\end{array}$ & $\begin{array}{l}\text { Mendominasi usaha/ } \\
\text { dominant }\end{array}$ \\
\hline Usaha pendederan/ & $\begin{array}{l}\text { Sudah ada, dilakukan } \\
\text { oleh responden/Already } \\
\text { existed, performed by } \\
\text { the respondents }\end{array}$ & $\begin{array}{l}\text { Belum ada/ } \\
\text { not available }\end{array}$ & $\begin{array}{l}\text { Mendominasi usaha/ } \\
\text { dominant }\end{array}$ \\
\hline Usaha pembesaran/ & $\begin{array}{l}\text { Banyak diusahakan/ } \\
\text { Many cultivated }\end{array}$ & $\begin{array}{l}\text { Masih coba-coba/ } \\
\text { still trial version }\end{array}$ & $\begin{array}{l}\text { Masih sedikit/ } \\
\text { Still slightly }\end{array}$ \\
\hline $\begin{array}{l}\text { Consumption } \\
\text { production }\end{array}$ & & & $\begin{array}{l}\text { diusahakan/ available } \\
\text { on location but still } \\
\text { slightly }\end{array}$ \\
\hline
\end{tabular}

Sumber/ source: Data primer, diolah (2009)/ Primary data, processed (2009)

\section{Skenario strategi intervensi}

Berdasarkan hasil survei, secara teknis usaha budidaya ikan sangat memungkinkan untuk dikembangkan. Hal ini didukung oleh beberapa kondisi usaha yang sudah ada serta karakteristik masyarakat yang diwakili dengan karakteristik responden, sebagian besar tergolong pada usia produktif sehingga usaha lebih memungkinkan untuk ditingkatkan.

Pendekatan analisis untuk melihat model pengembangan sistem usaha perikanan di lokasi dilakukan dengan model dinamik. Model utama yang dibangun adalah model kebutuhan pangan ikani. Dalam model ini menggambarkan keterkaitan antara jumlah penduduk dan kebutuhan ikan. Asumsi yang digunakan dalam model ini adalah tidak terjadi bencana alam atau wabah penyakit yang menyebabkan kematian masal, kematian penduduk disebabkan karena faktor alamiah, tingkat konsumsi ikan dipengaruhi oleh produksi ikan hasil budidaya ditambah ikan hasil penangkapan-penjualan ikan ke luar daerah - masuknya ikan dari wilayah lainstok-bukan makanan dibagi jumlah penduduk di wilayah tersebut. Namun demikian karena masih banyaknya kesulitan pencarian data, penghitungan konsumsi ikan biasanya tidak memasukkan jumlah stok serta persediaan bukan makanan.

\subsection{Desa Merakan}

Kasus di Desa Merakan, data konsumsi ikan penduduk Desa Merakan hanya 


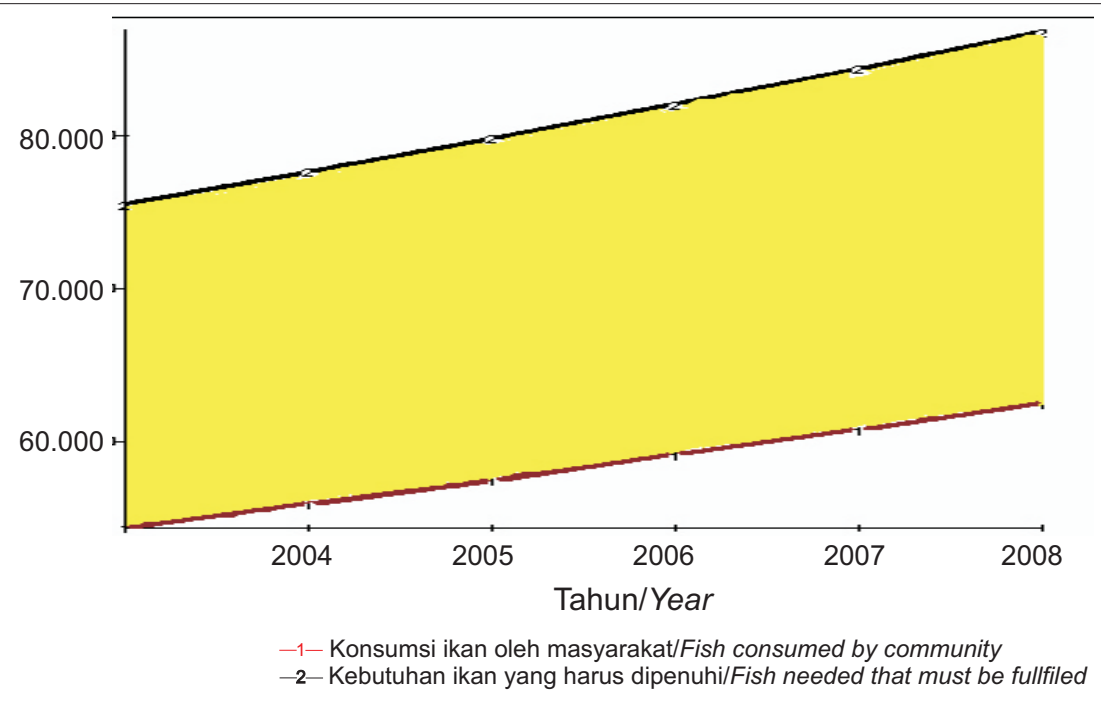

Gambar 2. Selisih Antara Kebutuhan Ikan Ideal dengan Tingkat Konsumsi Ikan

Figure 2. The Difference Between the Requirement for the Ideal Fish and the Level of Fish Consumption

sebanyak 18 kg/kapita/tahun (Anynomous, $2008^{\text {h}}$ ), seharusnya konsumsi ikan idealnya adalah $25 \mathrm{~kg} / \mathrm{kapita/tahun} \mathrm{(DKP).} \mathrm{Sehingga}$ ada selisih antara kebutuhan ikan yang harus dipenuhi dengan jumlah konsumsi ikan oleh masyarakat. Untuk memenuhi kebutuhan ikan, maka dibutuhkan pasokan ikan yang berasal dari daerah lain. Intervensi terhadap model dinamis dilakukan secara struktural. Hal ini disebabkan karena untuk memenuhi kebutuhan ikan di Desa Merakan membutuhkan supply ikan dari daerah lain. Perubahan model yaitu dengan menambahkan subsistem produksi ikan.

Pada subsistem produksi ikan, lup yang bekerja adalah lup positif antara produksi ikan dan selisih ntara permintaan dan penawaran (gap supply-demand). Dimana semakin tinggi produksi ikan yang dihasilkan akan menghasilkan gap supply demand ikan yang semakin besar pula. Sebaliknya semakin tinggi selisih antara permintaan dan penawaran (gap supply demand) ikan maka merupakan faktor pendorong produksi ikan, sehingga produksi ikan semakin besar. Selisih antara permintaan dan penawaran (gap supply demand) ini pun dipengaruhi oleh kebutuhan ikan ideal. Semakin banyak atau semakin besar kebutuhan ikan ideal, maka selisih ntara permintaan dan penawaran (gap supply-demand) ikan akan semakin besar pula. Intervensi model dapat dilihat pada Gambar 3.

Untuk memenuhi kebutuhan ikan yang harus dipenuhi, maka produksi ikan harus didorong dengan dua cara, yaitu intensifikasi dan ekstensifikasi. Intensifikasi produksi ikan melalui variabel jumlah tenaga kerja, obatobatan, kebutuhan benih dan jumlah pakan. Sedangkan ekstensifikasi dapat dilakukan dengan cara perluasan lahan efektif. Pada ekstensifikasi terdapat faktor pembatas yaitu luas lahan. Karena tidak mungkin seluruh areal dijadikan lahan budidaya ikan.

Dalam model ini intensifikasi produksi ikan dapat mendorong produksi sebesar $80 \%$ sedangkan ekstensifikasi mendapatkan porsi sebesar $20 \%$. Hasil simulasi yang diperoleh bila hal ini dilakukan, maka kebutuhan ikan ideal dapat terpenuhi dan tingkat konsumsi 


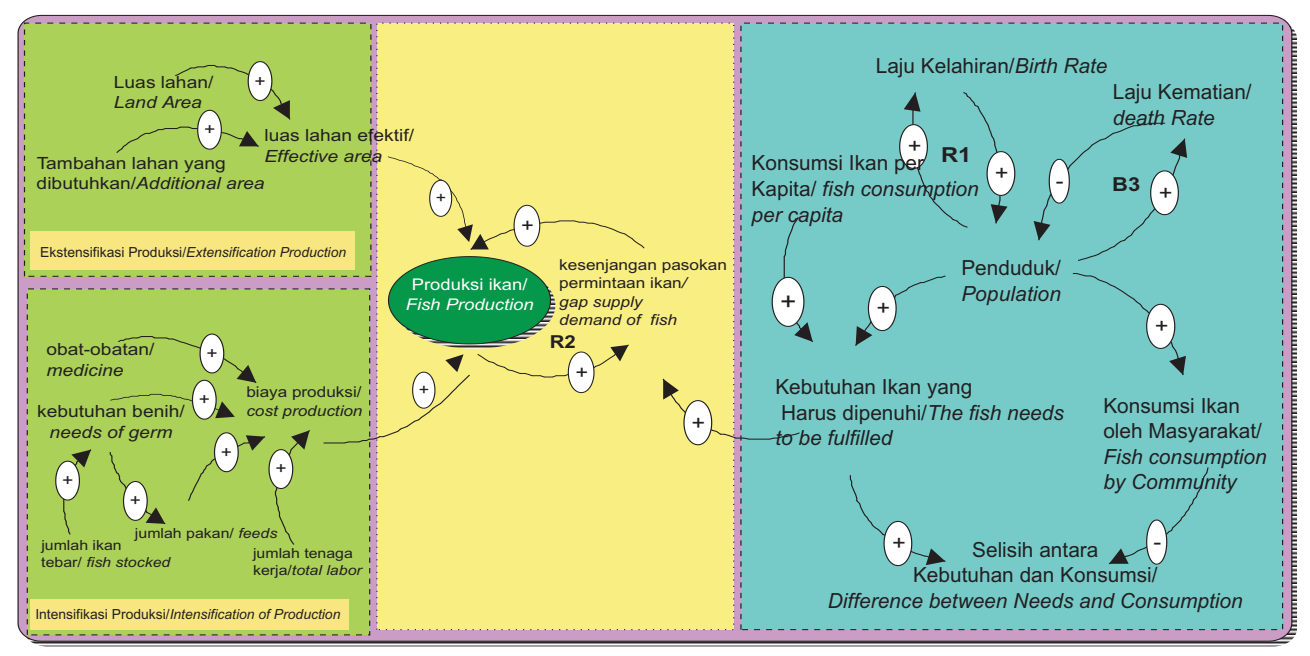

\section{Gambar 3. Model Ketahanan Pangan}

Figure 3.Food Security Model

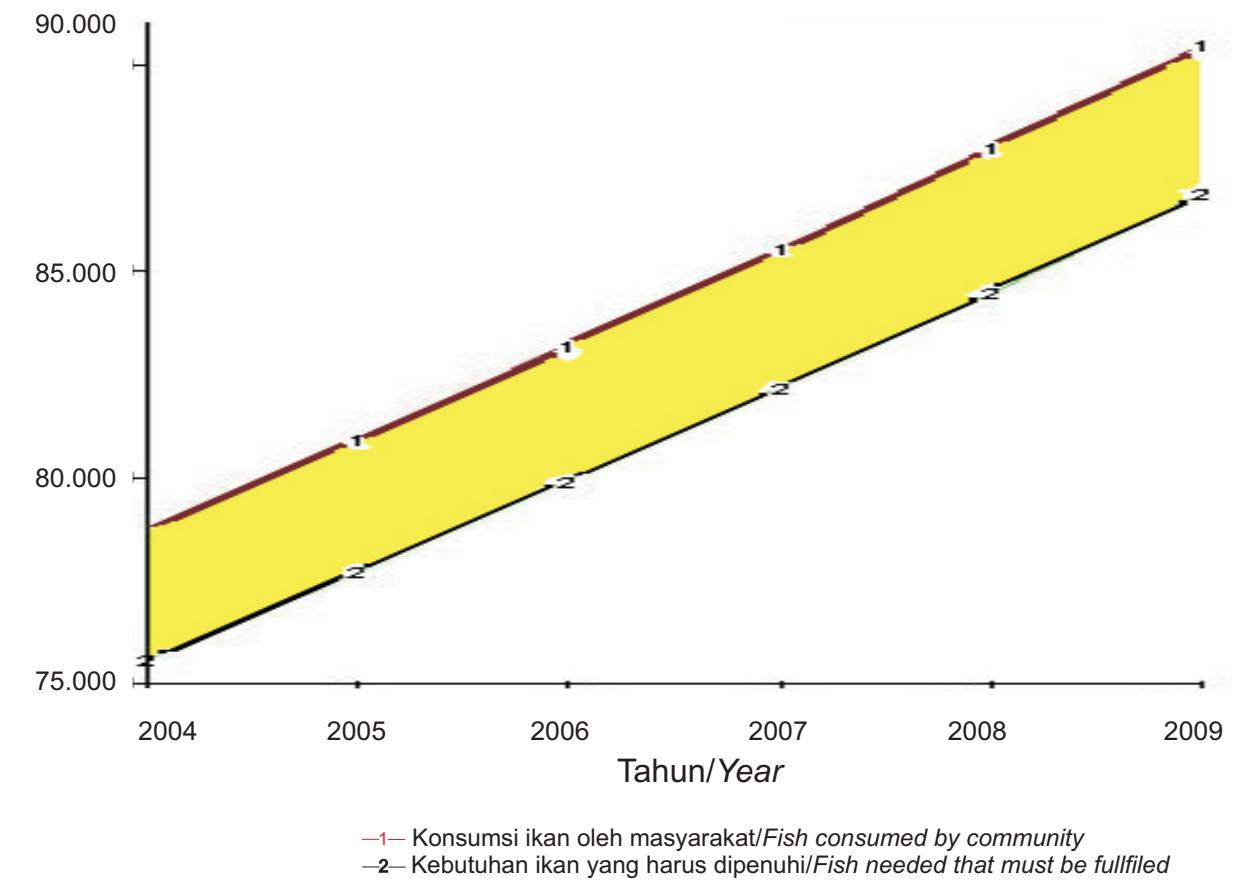

Gambar 4. Kecendrungan Konsumsi dan Kebutuhan Ikan di Desa Marakan, 2005-2009 Figure 4. Trend of Fish Consumption and Demand in Marakan Village, 2005-2009 
Tabel 4. Tingkat Konsumsi Ikan setelah Intervensi Model di Desa Merakan, 2004-2009 Table 4. Consumption of Fish after Model Intervention in Merakan Village, 2004-2009

\begin{tabular}{ccc}
\hline Tahun/Year & $\begin{array}{c}\text { Kebutuhan Ikan yang } \\
\text { harus Dipenuhi/ } \\
\text { The Requirement for the } \\
\text { Fish thatMust be Filled }\end{array}$ & $\begin{array}{c}\text { Jumlah ikan yang } \\
\text { dikonsumsi oleh masyarakat/ } \\
\text { Consumption of the Fish by } \\
\text { the Community }\end{array}$ \\
\hline 2004 & $75.625,00$ & $78.740,75$ \\
2005 & $77.759,83$ & $80.963,53$ \\
2006 & $79.954,92$ & $83.249,06$ \\
2007 & $82.211,97$ & $85.599,10$ \\
2008 & $84.532,74$ & $88.015,49$ \\
2009 & $86.919,02$ & $90.500,09$ \\
\hline
\end{tabular}

ikan menjadi $26,03 \mathrm{~kg} / \mathrm{kapita} / \mathrm{tahun}$. Peningkatan tingkat konsumsi ikan dapat dilihat pada Gambar 3 dan Tabel 4.

Berdasarkan hasil simulasi dalam model ini, maka untuk memenuhi kebutuhan ikan ideal ini, pada upaya intensifikasi maka kebutuhan benih yang diperlukan adalah sebanyak 500.000 ekor benih setiap bulannya. Sedangkan dari upaya ekstensifikasi diperlukan luas lahan sebesar $26.99 \mathrm{Ha}$.

Melihat kondisi di Desa Merakan, jumlah lahan dan kebutuhan benih yang disediakan tersebut untuk sementara tidak dapat sepenuhnya dilakukan di Desa Merakan. Hal ini disebabkan oleh berbagai keterbatasan sumber daya yang tersedia diantaranya lahan yang ada masih termasuk lahan kering dan ketersediaan air yang dibutuhkan tidak akan mencukupi sehingga alternatif pengusahaannya hanya dapat dikembangkan usaha pembesaran dan itupun tidak dapat dipenuhi hanya dari desa tersebut.

\subsection{Kasus Desa Watuurip}

Desa Watuurip ini berada di ketinggian $732 \mathrm{~m}$ di atas permukaan laut, yang kondisi wilayahnya terdiri dari $60 \%$ daratan dan $40 \%$ berupa perbukitan. Secara keseluruhan masyarakat di Kabupaten Banjarnegara tingkat konsumsi ikannya masih rendah karena hanya $9 \mathrm{~kg} / \mathrm{kapita} / \mathrm{tahun}$ dibandingkan dengan target pemerintah yaitu 26 $\mathrm{kg} / \mathrm{kapita/tahun.}$
Usaha pembenihan ikan di Kabupaten Banjarnegara sudah dimulai sejak tahun 2003 dan diarahkan untuk pengembangan usaha pembenihan dan pendederan ikan air tawar. Hasilnya saat ini Banjarnegara telah berhasil mengembangkan usaha pembenihan dan pendederan ikan air tawar khususnya untuk jenis-jenis ikan seperti ikan gurame, lele, nila dan saat ini berkembang patin.

Pemenuhan kebutuhan ikan bagi masyarakat khususnya di desa survey dapat dilakukan melalui pengembangan usaha pembesaran. Selama ini usaha yang berkembang di masyarakat tersebut hanya usaha pembenihan dan pendederan saja. Benih yang dihasilkan kemudian dijual keluar daerah dan tersebar di Jawa Tengah serta daerah lainnya. Akibatnya, harga ikan konsumsi di lokasi tersebut juga termasuk cukup mahal dibanding wilayah lainnya. Sebagai contoh harga ikan lele mencapai Rp $10.000 / \mathrm{kg}$, gurame Rp. 30.000/kg. Konsumsi ikan masyarakat juga terbatas pada ikan pindang yang diproduksi dari Pekalongan yang harganya murah yaitu hanya Rp. 2.000 per dua ekor.

Tentu saja harus diupayakan penyediaan ikan konsumsi masyarakat yang terjangkau dan cukup murah dengan kualitas yang baik pula. Salah satu solusinya yaitu dengan membangun sistem usaha pembesaran selain usaha pendederan dan 
pembenihan yang sudah berkembang. Pengembangan sistem usaha pembesaran tersebut akan menyebabkan konsekuensi adanya penyediaan jasa ikutan seperti input produksi serta permodalan untuk mendukung pengembangannnya.

Dari data yang diperoleh, di Desa Watuurip sudah tersedia sistem usaha perikanan terutama usaha pendederan dan pembenihan. Dari data konsumsi ikan masyarakat serta data konsumsi ikan ideal, terdapat gap selisih. Selisih tersebut dapat dilihat pada Gambar 5.

Pada Gambar 5 dibawah, terlihat target ikan yang harus dipenuhi agar masyarakat dapat memenuhi kebutuhan pangan ikani sesuai dengan tingkat konsumsi ikan yang ideal yaitu $25 \mathrm{~kg} / \mathrm{kap}$ ita/tahun. Rata-rata target ikan yang harus dipenuhi untuk mencapai tingkat konsumsi yang ideal, produksi ikan di Desa Watuurip harus mnyediakan pasokan ikan sebanyak $7.921,82 \mathrm{~kg}$. Target ikan yang harus dipenuhi dapat dilihat pada Tabel 5.

Model pengembangan sistem usaha perikanan hasil intervensi fungsional dari model dinamis, yaitu dengan mengubah nilai variabel. Upaya yang dilakukan adalah dengan cara ekstensifikasi lahan budidaya untuk usaha pembesaran. Bila pemanfaatan luas areal budidaya diperbesar menjadi $20 \%$, maka pada tahun 2017, kebutuhan ikan ideal dapat terpenuhi. Berdasarkan hasil simulasi, prediksi jumlah ikan yang dikonsumsi oleh masyarakat sebanyak 31.981,69 kg sedangkan jumlah kebutuhan idealnya hanya $31.565,03 \mathrm{~kg}$. Dengan penambahan luas areal, dapat meningkatkan jumlah produksi ikan, sehingga tingkat konsumsi ikan pun meningkat dan sesuai dengan tingkat konsumsi ikan yang dianjurkan (Tabel 6 dan Gambar 5 ).

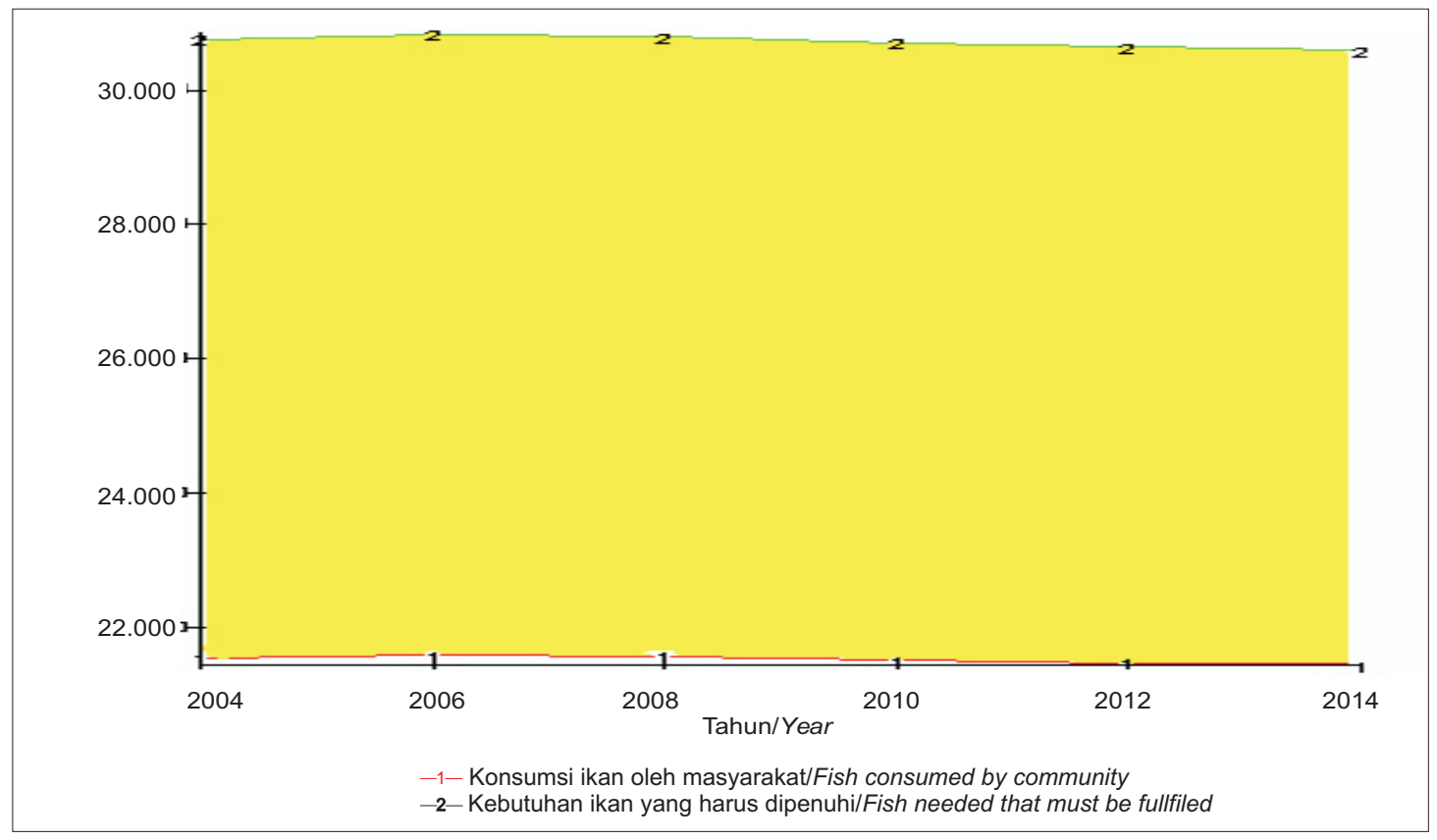

Gambar 5. Selisih Antara Kebutuhan Ikan yang harus dipenuhi dengan Konsumsi Ikan oleh Masyarakat di Desa Watuurip, 2004-2014.

Figure 5. The Difference Between the Requirement for the Fish That Must be Filled and Consumption of the Fish by the Community on Watuurip Village, 2004-2014. 
Tabel 5. Target Ikan yang Harus Dipenuhi di Desa Watuurip, 2004-2009

Table 5. Target of Fish Must to Be Fullfilled on Watuurip Village, 2004-2009

\begin{tabular}{cccc}
\hline Tahun & $\begin{array}{c}\text { Kebutuhan ikan yang } \\
\text { Harus Dipenuhi/The } \\
\text { Requirement for the } \\
\text { Fish That Must be } \\
\text { Fullfilled }\end{array}$ & $\begin{array}{c}\text { Konsumsi Ikan } \\
\text { oleh Masyarakat/ } \\
\text { fish Consumption } \\
\text { by Community }\end{array}$ & $\begin{array}{c}\text { Target Ikan yg harus } \\
\text { Dipenuhi/ The Fish } \\
\text { Target that Must be } \\
\text { Filled }\end{array}$ \\
\hline 2004 & $29.950,00$ & $22.043,20$ & $7.906,80$ \\
2005 & $29.883,63$ & $21.994,35$ & $7.889,28$ \\
2006 & $29.899,76$ & $22.006,22$ & $7.893,54$ \\
2007 & $29.992,60$ & $22.074,56$ & $7.918,05$ \\
2008 & $30.133,19$ & $22.178,03$ & $7.955,16$ \\
2009 & $30.182,14$ & $22.214,05$ & $7.968,09$ \\
\hline
\end{tabular}

Sumber: Hasil Simulasi Model / Source: Model Simulation

Tabel 6. Kebutuhan Ikan yang Harus Dipenuhi di Desa Watuurip, 2004-2019 Table 6. The Requirement for the Fish that Must be Filled on Watuurip Village,2004-2019

\begin{tabular}{lcc}
\hline Tahun/Year & $\begin{array}{c}\text { Kebutuhan Ikan Ideal/ } \\
\text { Ideal Number of Fish Needed }\end{array}$ & $\begin{array}{l}\text { Jumlah Ikan yang } \\
\text { dikonsumsi Real/Real Number } \\
\text { of Fish Consumed }\end{array}$ \\
\hline 2004 & $29.950,00$ & $15.334,40$ \\
2005 & $29.883,63$ & $15.730,74$ \\
2006 & $29.899,76$ & $16.361,15$ \\
2007 & $29.992,60$ & $17.251,75$ \\
2008 & $30.133,19$ & $18.718,74$ \\
2009 & $30.268,48$ & $20.134,59$ \\
2010 & $30.386,41$ & $20.820,77$ \\
2011 & $30.513,81$ & $21.396,28$ \\
2012 & $30.650,80$ & $22.227,96$ \\
2013 & $30.806,61$ & $23.203,54$ \\
2014 & $30.987,62$ & $24.207,53$ \\
2015 & $31.178,91$ & $27.100,71$ \\
2016 & $31.371,37$ & $31.158,05$ \\
2017 & $31.565,03$ & $31.981,69$ \\
2018 & $31.759,88$ & $32.433,19$ \\
2019 & $31.955,93$ & $32.889,05$ \\
\hline
\end{tabular}

Sumber: Hasil Simulasi Model/Source:Simulation Model

Dari Gambar 6 dapat dilihat bahwa dengan pengembangan usaha perikanan secara ekstensifikasi pada tahun 2017 sudah tercapai ditunjukkan dengan pertemuan garis antara kebutuhan ikan yang dikonsumsi dan ikan yang harus disediakan.
Dari hasil simulasi model dinamis yang dilakukan menunjukkan bahwa upaya peningkatan konsumsi ikan harus diikuti dengan pengembangan sistem usaha perikanan dari yang sudah ada saat ini menjadi sistem usaha yang baru yang 


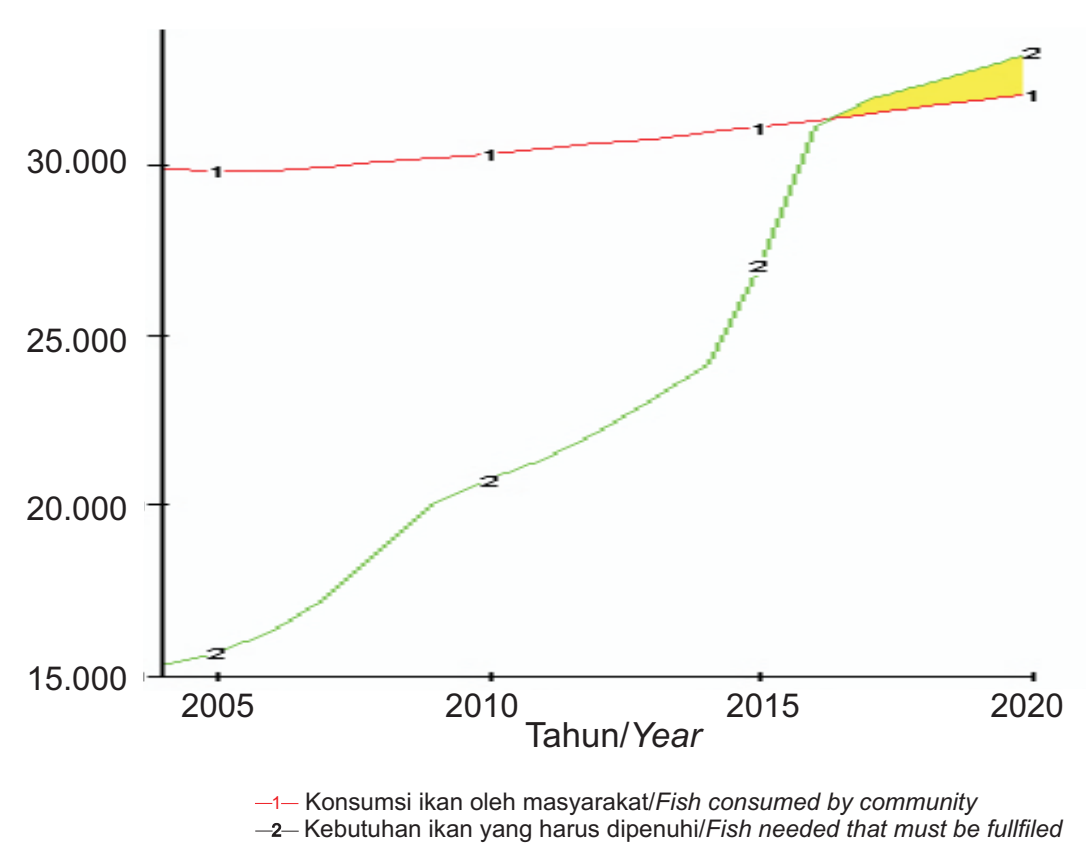

Gambar 6. Hasil Intervensi Model Dinamis

Figure 6. Intervention Result of Dynamic Model

memungkinkan terpenuhinya kebutuhan ikan ideal. Dari hasil simulasi diperlukan ekstensifikasi luas areal lahan yang diprioritaskan untuk usaha pembesaran seluas $8,86 \mathrm{Ha}$ dan jumlah benih ikan yang dibutuhkan sebanyak 886.780 ekor per bulan. $\mathrm{Hal}$ ini masih memungkinkan mengingat lahan potensial budidaya baru sekitar $8 \%$ dari 44,339 Ha yang termanfaatkan. Dari gambar dibawah dapat dilihat kondisi sistem usaha perikanan yang ada saat ini serta model pengembangannya ke depan terkait dengan pemenuhan konsumsi ikan masyarakat.

\subsection{Desa Salamrejo.}

Konsumsi ikan di Desa Salamrejo masih rendah yaitu $17 \mathrm{~kg} / \mathrm{kapita} / \mathrm{tahun}$ masih sangat rendah dibandingkan dengan target pemerintah $25 \mathrm{~kg} / \mathrm{kapita} / \mathrm{tahun}$. Pemenuhan tingkat konsumsi ikan ideal memberikan konsekuensi terhadap penyediaan ikan konsumsi yang harus disediakan. Melalui pengembangan sistem usaha perikanan yang di bangun, maka produksi ikan yang akan dicapai dapat terlaksana.

Dari hasil simulasi model, diketahui bahwa gap kebutuhan ikan ideal dengan konsumsi ikan real masyarakat dapat dilihat pada Gambar 7.

Pada Gambar 7, terlihat target ikan yang harus dipenuhi agar masyarakat dapat memenuhi kebutuhan pangan ikani sesuai dengan tingkat konsumsi ikan yang ideal yaitu $25 \mathrm{~kg} / \mathrm{kapita} /$ tahun. Rata-rata target ikan yang harus dipenuhi untuk mencapai tingkat konsumsi yang ideal, maka Desa Watuurip harus menambah pasokan ikan sebanyak $7.921,82 \mathrm{~kg}$. Target ikan yang harus dipenuhi dapat dilihat pada Tabel 8.

Dari hasil simulasi lebih lanjut diketahui bahwa pada tahun 2011 konsumsi ikan oleh masyarakat telah melebihi kebutuhan ikan yang harus dipenuhi. Tingkat konsumsi ikan pun meningkat dari $17 \mathrm{~kg} / \mathrm{kapita} / \mathrm{tahun}$ 


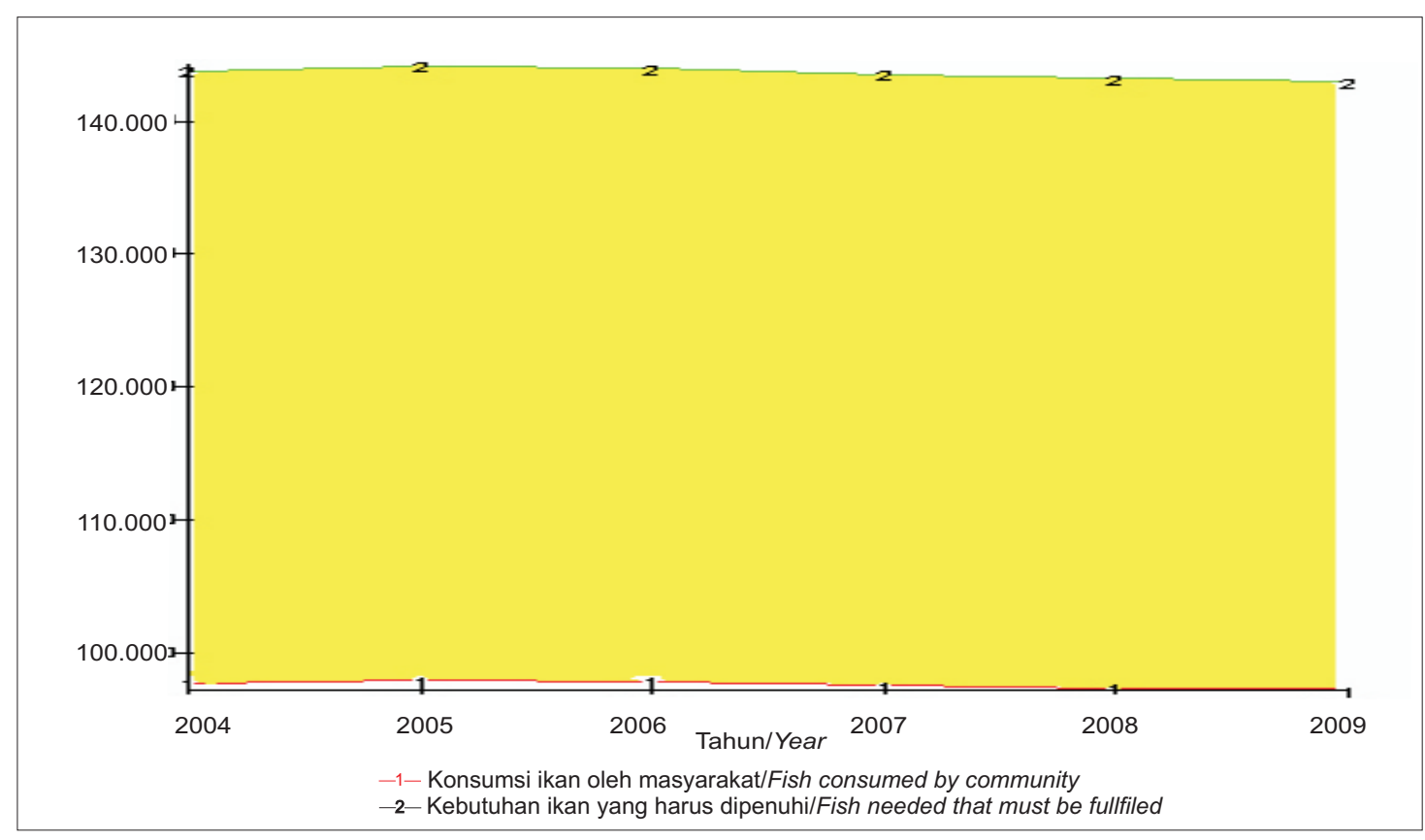

Gambar 7. Selisih Antara Kebutuhan Ikan yang Harus Dipenuhi dengan Konsumsi Ikan Oleh Masyarakat di Salamrejo, 2004-2009.

Figure 7. The Gap Between the Requirement for the Fish that Must be Fullfilled and Consumption of the Fish by the Community on Salamrejo Village, 2004-2009.

Tabel 8. Kebutuhan Ikan yang Harus Dipenuhi di Desa Salamrejo, 2004-2015 Table 8. Fish Requirement the Must be Fullfilled on Salamrejo Village,2004-2015

Tahun/Year

Kebutuhan Ikan yang harus Dipenuhi / Fish Requirement
Konsumsi Ikan oleh Masyarakat/ Consumed by Community

\begin{tabular}{rrr}
\hline 2004 & $143.850,00$ & $97.818,00$ \\
2005 & $144.225,20$ & $98.073,15$ \\
2006 & $144.041,20$ & $97.947,99$ \\
2007 & $143.624,80$ & $97.664,89$ \\
2008 & $143.256,10$ & $97.414,11$ \\
2009 & $142.980,70$ & $97.226,87$ \\
2010 & $143.029,40$ & $97.259,98$ \\
2011 & $143.634,60$ & $143.807,00$ \\
2012 & $144.897,10$ & $145.071,00$ \\
2013 & $146.976,80$ & $147.153,20$ \\
2014 & $150.199,80$ & $145.393,40$ \\
2015 & $154.140,40$ & $149.207,90$ \\
\hline
\end{tabular}

Sumber: Hasil Simulasi Model/ Simulation Model 
menjadi 25 kg/kapita/tahun. Dengan memperluas areal budidaya, maka benih yang dibutuhkan adalah 702.500 ekor benih/bulan.

Dilihat pada Gambar 8, kebutuhan ikan yang dikonsumsi melebihi ikan yang disediakan. Kebutuhan ikan ini mengikuti pola kecenderungan pertumbuhan penduduk. Di Desa Salamredjo terjadi kecenderungan penurunan jumlah penduduk mulai dari tahun 2005 sampai dengan 2009 (Anynomous, $\left.2007^{b}, 2008^{i}\right)$. Berdasarkan hasil simulasi, penduduk mengalami pertumbuhan setelah tahun 2010.

Untuk memenuhi kebutuhan pangan ikani ini, maka usaha perikanan yang sudah tersedia harus dapat lebih dikembangkan. Pengembangan sistem usaha perikanan dalam model ini maka dilakukan intervensi fungsional, yaitu dengan mengubah nilai variabel.

Upaya yang dilakukan untuk mencapai jumlah produksi pada tahun 2011 adalah dengan cara ekstensifikasi lahan budidaya. Luas lahan yang dimanfaatkan sebagai lahan budidaya masih sangat sedikit yaitu $0,8 \mathrm{Ha}$ (Anynomous, 2008, $2008^{\mathrm{b}}$ ). Berdasarkan hasil simulasi apabila areal budidaya diperluas sebesar $20 \%$ dari total budidaya atau sebesar 84,3 Ha, maka konsumsi ikan oleh masyarakat melebihi kebutuhan ikan yang harus dipenuhi. Tingkat konsumsi ikan pun meningkat dari $17 \mathrm{~kg} / \mathrm{kapita} / \mathrm{tahun}$ menjadi $25 \mathrm{~kg} / \mathrm{kapita} / \mathrm{tahun}$. Namun demikian apabila dilihat dari potensi desa luas lahan potensial yang tersedia untuk budidaya hanya 8,19 $\mathrm{Ha}$, sehingga alternatifnya dapat merubah fungsi lahan dari sawah menjadi kolam ikan atau dengan teknologi budidaya minapadi. Alternatif lain kekurangan ikan konsumsi dapat dipenuhi dengan mendatangkan ikan dari desa lain yang punya potensi cukup besar. Jumlah benih yang

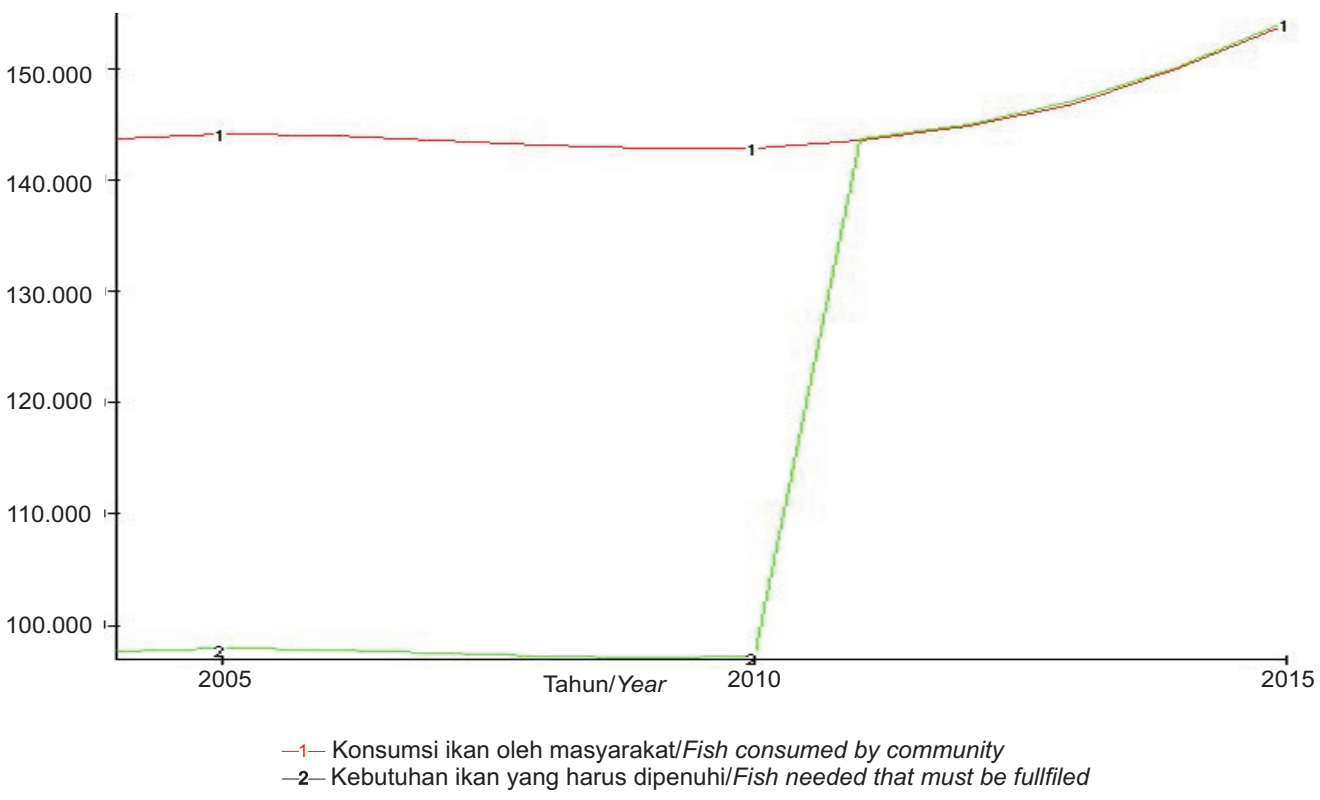

Gambar 8. Hasil Intervensi Model

Figure 8. Intervention Result Model 
dibutuhkan adalah 702.500 ekor benih/bulan. Kondisi saat ini , hanya satu orang pembenih yang sudah aktif tidak memungkinkan menghasilkan benih sejumlah itu, sehingga akan bergantung pada produsen benih dari lokasi lain.

Keragaan usaha perikanan khususnya budidaya ikan lele secara intensif di Desa Salamrejo sudah berlangsung selama satu tahun. Hasilnya saat ini Desa Salamrejo termasuk sebagai lokasi penghasil ikan lele di DI Jogjakarta. Usaha budidaya lele dilakukan menggunakan kolam-kolam terpal yang ditempatkan baik di lahan pekarangan maupun di kebun. Budidaya yang banyak dilakukan saat ini yaitu usaha pembesaran ikan lele untuk konsumsi. Namun demikian saat ini juga sudah mulai ada seorang yang berusaha untuk membenihkan dan mendederkan lele sehingga benihnya dijual ke pembudidaya yang ada di lokasi desa tersebut. Model pengembangan usaha perikanan di Desa Salamrejo dapat dilakukan untuk seluruh subsistem usaha (pembenihan, pendederan, pembesaran), namun demikian karena keterbatasan lahan, maka untuk mensuplai kebutuhan ikan konsumsi tetap harus mengandalkan ikan yang dihasilkan dari daerah lain yaitu Desa Sentolo yang cukup berpotensi.

\section{Pelajaran Umum dari Ketiga Kasus}

Berdasarkan informasi yang diperoleh dari hasil simulasi model dengan pendekatan sistem, maka strategi pengembangan usaha perikanan dapat dilakukan berdasarkan kategori kondisi wilayahnya. Pertama yaitu wilayah yang pengembangannya dapat dilakukan melalui cara ekstensifikasi (kasus Desa Merakan). Kedua, wilayah yang pengembangan usaha perikanannnya dapat dilakukan melalui ekstensifikasi dan intensifikasi (kasus Desa Salamredjo dan Desa Watuurip).

4.1 Desa Merakan (Kasus Desa Ekstensifikasi) i. Subsistem yang dapat dikembangkan adalah subsistem usaha pembesaran, jasa input produksi, permodalan serta pasar. Komoditas ikan yang paling tepat untuk dikembangkan adalah ikan lele. Kemungkinan lain yang relevan adalah komoditas yang dikembangkan memiliki prospek pasar yang baik.

ii. Subsistem pendederan dan pembesaran tidak dapat dikembangkan di desa Merakan, karena teknologi budidaya ikan belum dikuasai penduduk serta kondisi sumber daya air tidak cukup mendukung.

iii. Kehadiran subsistem jasa input produksi terutama pakan, pupuk dan obat-obatan serta kelembagaan pendukung dalam pengembangannya.

iv. Eksistensi jasa permodalan melalui dukungan pemerintah maupun dari pihak lain, mengingat kebutuhan modal yang cukup besar dalam investasi awal.

v. Subsistem pemasaran harus dibangun untuk mendukung lancarnya pasokan ikan kepada konsumen. Lembaga pemasaran yang sudah ada di desa seperti pedagang keliling, warung dan pasar perlu diberdayakan.

4.2 Desa Watuurip / Desa Salamredjo (Kasus Intensifikasi dan Ekstensifikasi)

i. Sistem usaha perikanan sebaiknya dibangun secara terpadu. Mengacu pada kasus Desa Watuurip, pemaduan usaha mulai pembenihan dan pendederan yang sebelumnya sudah ada membuat usaha masing-masing lebih menguntungkan.

ii. Subsistem usaha pembesaran paling berpotensi dikembangkan melalui usaha ekstensifikasi lahan. Namun demikian, ketersediaan benih sering menjadi faktor pembatas.

iii. Subsistem usaha pendederan serta pembenihan sering harus dipertimbangkan meskipun lokasi pembesaran maupun pasar di dalam wilayah tidak besar. Hal ini karena produksi yang dihasilkan tersebut 
berpotesi mendukung subsistem di wilayah lain sekaligus memberikan peluang peningkatan pendapatan, yang secara tidak langsung dapat dipergunakan untuk meningkatkan kemampuan pencukupan pangan.

iv. Subsistem input produksi, terutama pakan harus disediakan mencukup seluruh kebutuhan untuk usaha pembesaran yang akan dikembangkan. Hal ini dapat dilakukan dengan melancarkan distribusi serta membangun kelembagaan pensuplai input yang memadai.

v. Subsistem permodalan juga perlu dibangun untuk membantu pengembangan usaha pembesaran, karena usaha ini akan membutuhkan modal yang cukup besar terutama untuk penyediaan pakan. Kelembagaan permodalan harus dibentuk dengan tujuan tidak hanya mencari keuntungan tapi juga memberi kemudahan bagi pelaku usaha dalam meminjam modal usaha.

vi.Subsistem pemasaran menjadi sangat penting baik melalui pembentukan lembaga pemasaran juga dalam melancarkan distribusi ikan dari produsen ke konsumen. Lembaga pemasaran yang sudah ada sebelumnya yang hanya bergerak dalam jual beli benih, ke depan juga lebih diarahkan pada ikan konsumsi. Sarana berupa pasar yang ada lebih difungsikan kembali untuk menampung ikan konsumsi dari hasil produksi ikan yang dibudidayakan

\section{KESIMPULAN DAN IMPLIKASI KEBIJAKAN}

\section{Kesimpulan}

a. Berdasarkan pelajaran yang diperoleh dari kasus-kasus di lokasi survey, disimpulkan bahwa terdapat banyak peluang untuk pengembangan sistem usaha perikanan melalui bentuk intervensi tertentu.

b. Kasus Desa Watuurip (Desa Ekstensifikasi), subsistem yang dapat dikembangkan adalah subsistem usaha pembesaran, jasa input produksi, permodalan serta pasar

c. Kasus Desa Watuurip dan Salamredjo, pengembangan sistem usaha perikanan dapat dilakukan melalui intensifikasi dan ekstensifikasi.

\section{Implikasi Kebijakan}

Pengembangan usaha budidaya harus dilihat kondisi potensi wilayah tersebut dalam pengembangannnya. Pengembangan usaha budidaya tersebut harus didukung sepenuhnya oleh pemerintah terutama terkait dengan permodalan dan program terkait dengan pengentasan kemiskinan di wilayah rawan pangan. Di samping itu harus diberikan bimbingan dan pelatihan karena sebagian besar penduduk di lokasi rawan pangan tersebut masih minim informasi usaha budidaya. Pengembangan usaha budidaya dapat dilakukan dengan intensifikasi dan ekstensifikasi. Untuk usaha intensifikasi diperlukan peranan diseminasi teknologi ke wilayah rawan pangan, karena potensi peningkatan produksi untuk program ini akan dipenuhi melalui pemberian teknologi yang lebih maju. Untuk program ekstensifikasi dapat dilakukan dengan pemanfaatan lahan yang belum digunakan untuk usaha budidaya ikan, atau lahan sawah dengan budidaya tumpangsari antara padi dan ikan.

\section{DAFTAR PUSTAKA}

Annonimous. 2008'. Laporan Tahunan Dinas Perikanan dan Kelautan Kabupaten Kulonpogo DIY. Dinas Kelautan dan Perikanan Provinsi DIY., Yogyakarta.

2008 ${ }^{\mathrm{b}}$. Statistik Perikanan dan

Kelautan Dinas Perikanan dan Kelautan Kabupaten Kulonprogo DIY. Dinas Kelautan dan Perikanan Provinsi DIY., Yogyakarta. 2008. Laporan Tahunan Dinas Perikanan dan Kelautan Kabupaten Lumajang., Jawa Timur. 
.2008 ${ }^{\mathrm{d}}$. Statistik Perikanan dan Kelautan Dinas Perikanan dan Kelautan Kabupaten Lumajang., Jawa Timur. 2008. Laporan Tahunan Dinas Perikanan dan Kelautan Kabupaten Banjarnegara., Jawa Tengah.

. 2008. Statistik Perikanan dan Kelautan Dinas Perikanan dan Kelautan Kabupaten Banjarnegara., Jawa Tengah. .2008 ${ }^{\circ}$. Direktori Pangan Indonesia 2007. Komite Ketahanan Pangan., Jakarta.

2008 ${ }^{\mathrm{h}}$. Potensi dan Perkembangan Desa/Kelurahan Tahun 2007. Desa Merakan, Kabupaten Lumajang. Jawa Timur.

2008. Potensi dan Perkembangan Desa/Kelurahan Tahun 2007. Desa Salamredjo, Kecamatan Sentolo, Kabupaten. Kulonprogo, DIY.

. 2008. Potensi dan Perkembangan Desa/Kelurahan Tahun 2008 Desa Watuurip, Kabupaten Banjarnegara, Jawa Tengah.

. 2007 . Potensi dan Perkembangan Desa/Kelurahan Tahun 2007. Desa Merakan, Kabupaten Lumajang. Jawa Timur.

2007. Potensi dan perkembangan Desa/Kelurahan Tahun 2007. Desa Salamredjo, Kecamatan Sentolo, Kabupaten Kulonprogo, DIY $2007^{\circ}$. Potensi dan perkembangan Desa/Kelurahan Tahun 2007. Desa Watuurip, Kabupaten Banjarnegara, Jawa Tengah.
. 2007 . Peta Kerawanan Pangan Tingkat Desa Kabupaten Lumajang. Jawa Timur.

. 2007. Peta Kerawanan Pangan Tingkat desa Kabupaten Kulonprogo. DIY.

. 2007. Peta Kerawanan Pangan Tingkat Desa Kabupaten Banjarnegara. Jawa Tengah.

. 2000. Rencana Aksi Pangan dan Gizi Nasional 2001-2005. Pemerintah Indonesia dan World Health Organization.

Aswatini, Romdiati, H., Setiawan, Bayu., Latifa, A., Fitranita dan Noveria, M. 2004. Ketahanan Pangan, Kemiskinan dan Sosial Demografi Rumah Tangga. Pusat Penelitian Kependudukan, Lembaga IImu Pengetahuan Indonesia (PPK-LIPI)., Jakarta.

Muhammadi, E. A. dan B. Soesilo. 2001. Analisis Sistem Dinamis: Lingkungan Hidup, Sosial, Ekonomi, Manajemen. UMJ Press., jakarta.

Saragih, B. 2001. Agribisnis-Paradigma Baru Pembangunan Ekonomi Berbasis Petanian. PT. Loji Grafika., Jakarta.

Sudana. 2010. EVALUASI-KINERJAD I SEM I NAS I - TEKNOLOG I INTEGRASI-TERNAK-KAMBING-DANKOPIDI BONGANCINA BALI. http://www.docstoc.com/docs/21596683 . Diakses tanggal 16 Maret 2010. 